\section{Unscientific postscript}

John C. Marshall

Ludwig Wittgenstein. A Student's Memoir. By Theodore Redpath. Duckworth: 1990. Pp.109. £12.95.

SOME forty years after his death, the cult of Ludwig Wittgenstein burns more fiercely than ever. Scarce a week goes by but that some elderly gentleman remembers (and publishes!) a chance remark that Wittgenstein made when tying his shoelaces; for every (relatively lucid) sentence that Wittgenstein wrote there must now be thousands of pages of (exceedingly dense) exegesis in print. Here, then, is one of the profound mysteries of the twentieth century: how did a minor Viennese aphorist come to be regarded (in some circles) as a great philosopher who had twice changed the course of that discipline, first with the Tractatus (1921) and then the Philosophical Investigations (1953)?

Theodore Redpath attended Wittgenstein's Cambridge 'happenings' (they can hardly be called lectures or seminars) from 1934 to 1936 , and from 1938 to 1940 . By then, the myth of the shaman was already well-established. I. A. Richards recommended attendance at the shrine in Trinity College with the claim "that Wittgenstein lived like a saint, that he was 'beautiful', but that he wore himself out during the course of a term's lecturing and that the ravages the effort made on him were terrible". And all this, Redpath reports Wittgenstein as saying at the first meeting, merely to help cure any students who might be "suffering from a particular kind of mental cramp".

Redpath himself seems to have been taken in rather less than most; to him, Wittgenstein looked "more like an active general than the mystical philosopher whose appearance I had concocted in the crannies of my brain". But Redpath seems also to have missed the point of the performance: for this is the Wittgenstein who tried to convince his youthful disciples that it was an error of grammar to imagine that appearances could be represented in the brain (or the mind). To this very day, the acolytes of north Oxford preach that current cognitive psychology, artificial intelligence and neuroscience are all based upon an awful mistake: the Wittgenstein - has twice changed the course of philosophy. purported failure to realize that language games, not empirical (and theoretical) inquiry, explicate the mental.

When Wittgenstein was still a young engineer, a brief chat with the likes of Alan Turing or Kenneth Craik could (perhaps) have saved him. Sadly, by the time the three men were simultaneously resident in Cambridge, Wittgenstein was living his own legend. His mental cramp had ossified to such an extent he could not see that his approach to psychology was strictly analogous to arguing that astronomy should be bounded by analysis

of the sentence 'The Sun rises in the east and sets in the west'.

How this tragic waste of a fine intellect came about would form a fascinating biography. Yet the first volume of the official biography (by Brian McGuinness, published by Duckworth in 1988) sheds little light on the early development of Wittgenstein's personality, and more by what is suppressed than by what is included.

When Wittgenstein left Vienna for Manchester and Cambridge before the 1914-18 war, to what extent was he avoiding competition with the intellectual and artistic genius of the Hapsburg capital? Was he later aware of recreating at Trinity the kind of superheated circus that once gathered around Arthur Schnitzler at the Café Griensteidl, or Peter Altenberg at the Café Central? Did he intentionally choose students in a strange land who would be incapable of understanding who he was and what he taught? Redpath recounts how Wittgenstein (normally tieless) borrowed tails from him for a formal dinner at Trinity. Afterwards, "he had the laundering done by the Wellbrook Laundry at Girton. Wittgenstein thought highly of it, and later my family transferred to it." That it should come to this for a man in whose family house, on the Alleegasse, Johannes Brahms and Clara Schumann had played piano duets.

But the Empire did not pass away without pain. As an artillery officer on the eastern front, what guilt did Wittgenstein incur as he observed, indeed participated in, the slaughter

of his people when the armies of the Emperor and the Tzar swept over the defenceless shtetlach of Galicia and Bukovina? Little wonder, then, that the Tractatus, drafted in field-pencil at the front, should end: "Wovon man nicht sprechen kann, darüber muss man schweigen" (Whereof one cannot speak, thereof one must be silent).

John C. Marshall is at the Neuropsychology Unit, University Department of Clinical Neurology. The Radcliffe Infirmary, Oxford OX2 $6 \mathrm{HE}$, UK. 